formulations are identical. The active ingredient of the remedy used by our patient, psoralen, is used together with ultraviolet irradiation in orthodox dermatological practice in treating disorders such as psoriasis. The problem here, therefore, was not the active ingredient in itself but the quantity of it present in the powdered seeds that our patient used, which resulted in a relative overdose. We believe that it is safer medical practice to give the pharmacologically active ingredient in a purified form and controlled dose rather than in an unknown dose together with a medley of other products.

Mr Farrell and Dr Lamb do not enhance the reputation of herbalism when they state that "no information is available on the number of people taking such [herbal] remedies without adverse effects" and "little has been published on the efficacy of herbal remedies." We do not think that any new drug would be granted a product licence on this basis.

P D L MAURICE J J CREAM

Department of Dermatology

Charing Cross Hospital

London W6 8RF

\section{Personal views}

SIR, - Abortion counselling should be more abou the conscience of the mother than the conscience of the doctor, but Dr Jonathan Richards should not believe that it can be dispassionate.' It can, and should, be compassionate, but in such an emotive ethical issue as legal abortion it is not possible for the counsellor to disguise his or her own attitudes. Those who hide under the notion that their counselling is "non-directive" and "non-judgmental" are directing the patient and making judgments for her just as much as those who allow morality to enter into their discussion.

The doctors who should withdraw from the abortion scene are those who seldom encourage an ambivalent mother successfully to continue with her pregnancy and, equally, those who are not prepared to countenance legal abortion under any circumstances. Medicine needs more doctors like Dr Richards who shed tears for the fetus.

In the case of teenage girls who seek legal abortion but who do not want their parents to know about their condition, it is my normal practice to advise them strongly to reveal their dilemma to their guardians. Often it is only when this is done that a rational decision can be made. Fear of parental disapproval is not a legitimate reason for termination of pregnancy, but in the case of many young girls it is the main reason for their seeking medical help.

DAVID R MILLAR

\section{Jessop Hospital for Women,}

Sheffield S3 7RE

1 Richards J. Today I laid hands on a baby condemned to death BrMed F 1989;299:1345. (25 November.)

SIR,-D Dr Jonathan Richards illustrates the dilemma faced by doctors counselling patients requesting abortion when those doctors passionately hold moral objections to pregnancy termination. He had vowed not to be the sort of doctor "who would refuse to help someone who held a different ethical view" from him, and questioned that stand. He compared the ethics of abortion with those of diet, smoking, and drinking habits.

Dr Richards appeals for answers to his dilemma, which he sees as a choice between deserting his community and discarding his beliefs. I contend that his use of those options is greatly mistaken and compounds his dilemma. He is further mistaken in believing that the mother's right to undergo abortion need, or should, involve him. I would advise him to consider withdrawing from this counselling. He is aware that society allows him honourably to do this, and the consequences are not that women will obtain abortions without proper consultation. The reality is that many doctors are not opposed to abortions, and those doctors are beter placed dispassionately to assess the individual cases and counsel as necessary. Good though Dr Richards's intentions and actions are, how can he be expected to strive to achieve unbiased counselling when he views abortion as condemning a baby to death? In my opinion, counselling for abortion should be done only by those who are not against abortion.

A vow not to allow one's ethical view to influence treatment is untenable. Our actions are inevitably a function of our personal ethics, standards, and beliefs; although we should strive to treat patients irrespective of their beliefs, we are not expected by society to do so if our actions transgress our own beliefs.

The broader issues of abortion are of secondary importance to our personal ethics. Maternal anguish occurs even in the best counselled cases, and the issue of the re-emergence of lethal illegal abortions is academic while a large proportion of doctors are not against abortion.

LYNDON MILES

Merthyr Tydfil

Mid Glamorgan

Richards J. Today I laid hands on a baby condemned to death. Br.Med ' 1989:299:1345, 25 November.

SIR,-Dr Jonathan Richards describes his upset and confusion in counselling a woman seeking an abortion and his wish to withdraw because he cannot cope with how he feels.' His situation closely parallels that of his patient: both he and she face a choice between making contact with and commitment to another (for him, his patient; for her, the unborn child) or withdrawing and so losing both burdens and rewards.

The way that he helped his patient out of her dilemma would serve him equally well: a caring but dispassionate relationship-call it counselling, support, or supervision, as you will-in which to give vent to and understand his feelings (for it is clear that he must mourn the child that he has had a part in killing) and then decide his course of action with a clear mind and carry it through with a clear conscience. In the context of such a relationship he could almost certainly continue to offer his obvious gift for counselling to his patients.

Personal support for a counsellor is as much a tool of the trade as an electrocardiograph for a cardiologist; the job cannot be done efficiently or effectively without it. Until this is reeognised by the medical profession, doctors like Jonathan Richards will continue to "burn out" at considerable cost in terms of distress to themselves and loss of their skills to their patients.

JOHN BARUCH

CRC Psychological Medicine Group Roval Marsden Hospital Sutton SM2 5P'

1 Richards J. Today I laid hands on a baby condemned to death. Br.Med f 1989:299:1345. (25 November.

\section{Treatment of persistent pain}

SIR, - In the north of England there is already good recognition and utilisation of behavioural methods of relieving chronic pain mentioned by Dr C E Pither. ' Cognitive behavioural programmes have existed here for many years, starting with that run by Professor Bond in Glasgow throughout this decade. At our pain relief unit at Walton Hospital 622 patients have completed a four week rehabilitation programme since 1983 . Over $31 \%$ of those available for paid employment have returned to work, and there have been appreciable decreases in utilisation of drugs, health service facilities, and sickness benefits. Interim results have been presented at numerous meetings, and five year follow up studies are now nearing completion and will be presented in 1990. A self help group has been set up by the patients who have completed our programme; this group is now a registered charity and is developing subgroups around the country. We know of at least 12 groups that have started such a programme after visiting us and hope that resources are made available for those many others who are interested in treating the endemic condition of persistent pain in an effective way.

J C D WELLS E GHADIALI

Centre for Pain Relief,

W'alton Hospital, Liverpool L9 $1 \mathrm{AE}$

1 Pither CE. Treatment of persistent pain. BrMed f 1989;299:1239. (18 November.)

\section{Treatment protocols, specialist centres, and end results}

SIR,-Dr Mark McCarthy correctly stated' that one of the strengths of the recent study of survival for multiple myeloma in Finland ${ }^{2}$ is that it is population based.

Uniquely among the studies cited in my review of referral patterns, entry to trials, and survival rates, ' the Finnish study compared survival rates between populations of geographically defined areas. All of the other comparative studies of referral and entry to trials were, however, population based in the sense that cases were ascertained from reasonably complete population based cancer registries such as the National Cancer Registration Scheme, the National Registry of Childhood Tumours, "I" the Greater Delaware Valley Pediatric Tumor Registry, "1: or the Thames Cancer Registry. ${ }^{12}$ The more recent Medical Research Council's report on acute lymphoblastic leukaemia $^{14}$ did not compare survival between specialist centres and other hospitals but reported trends in survival within the United Kingdom acute lymphatic leukaemia trials.

For solid tumours it would be of dubious value to compare survival among different types of hospital or between trial and non-trial patients, allowing for tumour stage, as we could not be sure that all patients had had the same investigations. Nevertheless, neuroblastoma is distinctive among paediatric cancers in that early stage tumours may be cured readily without systemic treatment whereas the outlook for patients with advanced disease is particularly poor. "It is surely reasonable therefore to suggest that non-specialist centres may have had a higher proportion of patients with localised tumours as most of their survivors were apparently cured without chemotherapy.

For acute lymphoblastic leukaemia the most important clinical determinants of prognosis are the age and white cell count of the patients. These factors were taken into account in the population based studies of survival of 327 children with acute lymphoblastic leukaemia in the Greater Delaware Valley" and of over 4000 children in Britain," but it would presumably have been impracticable to do so in the earlier but much smaller series of 52 children with acute lymphoblastic leukaemia in the Thames regions.

C A STILLER

Childhood Cancer Rescarch (iroup.

Radcliffe Infirmary, Oxford ( $1 \mathrm{X}_{2} 6 \mathrm{HH}$

114. Carthy M. Do treatment protecels improve end recultse Br 11ed 1989:299:1281 i18 Nowember

Karialainen S, Palla 1. Do treatment protocols improse end results? A studs of patients with multiple mveloma in Finland Br the of pattents with mo

3 Stiller CA. Survival of patients with cancer. $B r$ Med 71989 299:1058-9.

+ MRC Report to the council from the Committee on Leukacmia and Working Party on I, cukaemia in Childhood. Duration of 
survival in children with acute leukaemia. Br Med $y$ 1971;iv:7-9.

5 Lennox EL, Draper GJ, Sanders BM. Retinoblastoma: a study of natural history and prognosis of 268 cases. $\mathrm{Br}$.Med $\mathrm{F}$ 1975;iii: 731-4.

6 Lennox EL, Stiller CA, Morris Jones PH, Kinnier Wilson LM. Nephroblastoma: treatment during 1970-73 and the effect on survival of inclusion in the first MRC trial. $\mathrm{Br}$ Med $\mathrm{f}$ 1979;ii:567-9.

7 Stiller CA. Centralisation of treatment and survival rates for cancer Arch Dis Child 1988:63:23-30.

8 Sanders BM, Draper GJ, Kingston JE. Retinoblastoma in Britain 1969-1980: incidence, treatment and survival. Britain 1969-1980: incidence,
$B r$ Ophthalmol 1988;72:576-83.

9 Stiller CA, Draper GJ. Treatment centre size, entry to trials and survival in acute lymphoblastic leukaemia. Arch Dis Child 1989;64:657-61.

10 Pritchard J, Stiller CA, Lennox EL. Overtreatment of children with Wilms' tumour outside paediatric oncology centres. BrMed f 1989;299:835-6.

11 Meadows AT, Kramer S, Hopson R, Lustbader E, Jarrett P, Evans AE. Survival in childhood acute lymphocytic leukaemia: effect of protocol and place of treatment. Cancer Invest 1983;1:49-55.

12 Kramer S, Meadows AT, Pastore G, et al. Influence of place of treatment on diagnosis, treatment and survival in three pediatric solid tumors. I Clin Oncol 1984:2:917-23.

13 Gill M, McCarthy M, Murrells T, Silcocks P. Chemotherapy for the primary treatment of osteosarcoma: population effectivethe primary treatment of osteosarcoma: p
ness over 20 years. Lancet 1988;i.689-92.

14 MRC Report to Council Working Party on Leukaemia in Childhood. Improvement in treatment for children with acute
Cince Report to Council Working Party on Leukaemia in lymphoblastic leukaemia. Lancet 1986; ; $408-11$.

15 Voute PA. Neuroblastoma. In: Sutow WW, Fernbach DJ, Vietti TJ, eds. Clinical pediatric oncology. 3rd ed. St Louis: Mosby, 1984:559-87.

16 McCarthy M. Medical care of childhood leukaemia. Lancet 1975; i:1128-30

\section{In spectacular retreat?}

SIR,-Dr S B Lucas accuses me of misleading readers by portraying leprosy as "in spectacular retreat." In fact, these words were added by another hand across the top of my piece, in which I specifically repudiated the view that leprosy is on the wane. My figures of 10-12 million leprosy victims world wide and some 1600 million people exposed to the infection show that $I$ am in total agreement with Dr Lucas. It is doubly bothersome to be misrepresented on such an important issue and then to be attacked in print, without prior consultation, for something I did not say.

BERNARD DIXON

Ruislip Manor HA4 6AW

**We apologise for the fact that Dr Dixon did not see a copy of Dr Lucas's letter before it was published and for the misleading heading to the original article. $-\mathrm{ED}, B M \mathcal{H}$.

\section{Hazards of blood splashes}

SIR,-Orthopaedic surgeons are particularly at risk of being splashed with body fluids' because of the large number of procedures involving saws or drills. ${ }^{2}$ Many studies show the risks now faced by surgeons. The target cell for HIV is present in intact skin, and this implies that it is no longer necessary to have a cut to permit transmission; infected blood coming into contact with unbroken skin is sufficient. ${ }^{3}$ Various authors have shown that gloves may be perforated in up to $50 \%$ of operations $^{+5}$ and that needlestick injuries are inevitable. ${ }^{\circ}$ Day, who has done much to highlight these risks, is further concerned about the risks of inhaling live organisms that penetrate standard surgical masks.

Yet in the face of this alarming evidence the resources committed to improving safety are scant. The issue of screening all patients is fraught with all sorts of misconceptions. These were well illustrated by an item on the BBC's radio programme Any Questions last year: the panel were asked if they thought that all surgeons should have their HIV state checked regularly. All four of the great and good assembled there agreed that it would be a very good idea, and one of them added that he couldn't think that any doctor would object. In reality, there have been at least 16 documented episodes of health care workers without other risk factors acquiring HIV from patients, and none the other way round.

Protective clothing is deplorably deficient, and nowhere is this more so than in the matter of surgical gloves. The marketing director for Regent gloves, the brand leader, tells me that progress on this matter is slow and is likely to remain so. The manufacturer, LRC, is said to be looking at whether it might be possible to reinforce vulnerable areas of the glove. Biogel gloves are lubricated with cetylpyridinium chloride, which is toxic to HIV in vitro, though it is not known whether there is a similar effect in vivo.

But in general it is scandalous that it remains a case of everyone for themself. Surgeons are reduced to bizarre ad hoc protection such as a thimble on the index finger of the non-dominant hand (this is the site of $30 \%$ of hand injuries) ${ }^{4}$ or removing the fingers from leather golfing gloves and wearing them beneath a conventional pair of gloves. ${ }^{10}$

If the safety at work legislation is to mean anything then it is high time that the Department of Health turned its attention to how its key operatives can best be protected from these well documented hazards.

J H JESSOP

University Department of Orthopaedic Surgery,

Royal National Orthopaedic Hospital,

Stanmore, Middlesex HA 7 4LP

1 Brearley S, Buist LJ. Blood splashes: an underestimated hazard to surgeons. Br Med f 1989;299:1315. (25 November.

Duthie GS, Johnson SR, Packer GJ, Mackie IG. Eye protection, HIV and orthopaedic surgery. Lancet $1988 ; 1: 481-2$.

Braathen LR, Ramirez G, Kunze ROF, Gelderblom H. Langerhans cells.are primary target cells for HIV infection. Lancet 1987;ii: 1094 .

Brough SJ, Hunt TM, Barrie WW. Surgical glove perforation. Br f Surg 1988:75:317.

Matta H, Thompson AM, Ruiney HB. Does wearing two pairs of gloves protect operating staff from skin contamination? Br.Med f 1988:297:597-8.

6 Hussain SA, Latif ABA, Chaudhary AAAA. Risk to surgeons: a survey of accidental injuries during operations. Br $\mathcal{f}$ Surg 1988:75:314-6

7 Day LJ. AIDS: an occupational hazard for orthopaedic surgeons? Orthop Rev 1989;18:493-7.

8 Anonymous. AIDS and the orthopaedic surgeon. London: British Orthopaedic Association, 1989.

9 Miles AJG, Wastell C, Marsh TGA. Protection for the left index finger whilst operating on HIV positive patients. Ann R Coll Surg Engl 1988;70:225.

10 Jessop JH. Surgeons in the firing line as AIDS virus spreads. Health Service fournal 1988 February 25:249.

\section{Conductive education}

SIR, - I am a senior nurse for children with special needs, coordinating services for such children and concerned with an early intervention scheme for preschool children. Last year I spent an intensive week in Hungary looking briefly at conductive education. I have just returned from the Petö Institute, ${ }^{\prime}$ where I attended a course for international professionals.

I spent many hours observing the kindergarten for children with spina bifida and wondered about the damaging effect of the long "potting" sessions, the bear walking, and unsupported weight bearing for long periods, but the children were happy and mobile and seemed to be oblivious of their defects. They would be able to attend school and receive education once they were fully mobile and continent, in a society which has little tolerance of wheelchairs and scant resources for the handicapped. They would be less of a financial burden to their families.

In Britain we take it for granted that medical supplies and staff are available to those who need them. In Hungary it is unrealistic to expect district and school nurses to catheterise children in school unless the parents can afford to pay. The urinary output charts that I saw at the institute showed that the children were achieving a high degree of urinary continence after three years' attendance at the kindergarten. Many of our children in Britain still require catheterisation well into primary school. Therefore we must be careful about criticising methods that are appropriate in Hungary.

What alarmed me more than any of the practices I saw at the institute was the condition of two children who had recently arrived from Britain. Our services had achieved neither mobility nor continence in these children, nor had they prevented deformities from occurring. Another 4 year old British child was immobile when he arrived at the institute, and after seven weeks there he was walking with tripods. His mother said she had been told that he would never walk, and she had been discouraged from even allowing him to try. Other parents had stories to tell about the lack of medical and educational support in the areas in which they live.

The British parents had one thing in common: none of them wanted to be in Hungary. They would have preferred to receive adequate services at home. None of them seemed to know what conductive education is but were happy to have someone working intensively with their child, even though they may have recognised that the educational content of the programme was somewhat lacking by Western standards.

At the institute more and more emphasis is being put on early treatment and on prevention. Some Hungarian children start treatment as early as 6 months of age, and the institute reports good results.

A great deal of good work is going on around Britain that never receives publicity, but while there are parents who feel that they must go to Hungary to receive adequate support and treatment there is scope for some British professionals to examine closely their practice. We can learn a great deal from the Hungarians, but we must not try to replicate a system that makes sense only in Hungary.

4l Gaddum Road, Bowdon,

M MCKINLAY

Altrincham, Cheshire

1 Robinson RO, McCarthy GT, Little TM. Conductive education the Petö Institute, Budapest. Br Med $\mathcal{J}$ 1989;299:1145-9. 4 November.)

\section{Laying down the law on AIDS}

SIR, - The book edited by Dai Harris and Richard Haigh mentioned in the news item on AIDS and the law' deals with, among other things, the legal aspects of employment. ${ }^{2}$ Quite apart from the legal implications, good public health practice requires that we adopt measures that do not discriminate against people with HIV infection or at risk of becoming infected with HIV. ${ }^{3+}$ As the NHS is the largest employer in the United Kingdom we believe it should set an example in this regard. We recently carried out a survey of district health authorities in England to determine if they had formulated a policy on AIDS and personnel along the lines suggested by the World Health Organisation and the International Labour Organisation. ${ }^{50}$

Of 189 district health authorities contacted, 150 $(79 \%)$ responded; 67 had a policy on AIDS, and of the others 35 were developing a policy and 28 said that AIDS was covered in other personnel policies. Not all those that had a policy had covered all the points the WHO and ILO recommend. Six authorities had not addressed the questions of nondismissal, non-discrimination, training, and information. More than half of those that had a policy had not made a clear statement that it would be a disciplinary matter to refuse care, divulge information about another employee, or discriminate against members of staff on grounds of AIDS or lifestyle.

Only 32 personnel officers responded positively to all the four questions relating to attitude. Six thought a policy would actually alienate staff in high risk groups, 32 did not think people from risk 